University for Business and Technology in Kosovo

UBT Knowledge Center

UBT International Conference

2015 UBT International Conference

Nov 7th, 9:00 AM - 5:00 PM

\title{
The CISG applicability under the reservations
}

Erveina Gosalci

University for Business and Technology, gosalci@ubt-uni.net

Follow this and additional works at: https://knowledgecenter.ubt-uni.net/conference

Part of the Law Commons

\section{Recommended Citation}

Gosalci, Erveina, "The CISG applicability under the reservations" (2015). UBT International Conference. 1. https://knowledgecenter.ubt-uni.net/conference/2015/all-events/1

This Event is brought to you for free and open access by the Publication and Journals at UBT Knowledge Center. It has been accepted for inclusion in UBT International Conference by an authorized administrator of UBT Knowledge Center. For more information, please contact knowledge.center@ubt-uni.net. 


\title{
The CISG applicability under the reservations
}

\author{
Erveina Gosalci \\ UBT - Higher Education Institution \\ erveina.gosalci@ubt-uni.net
}

\begin{abstract}
The United Nations Convention on Contracts for the International Sale of Goods (CISG) is an important example of attempts towards the unification of the international private law. The CISG is seen as a big success with seventy nine contraction states, most of them are important states that lead and rule the world's largest economies. The set goal of CISG to achieve a uniformed law-Loi uniforme (because the states which has signed, ratified and applied it; by doing so the character of UNIFORME Law becomes clear as CISG aims to create uniform rules followed by uniform interpretation However is it entirely true that CISG creates uniformity in contracts for international sales of goods but there are also countries such United Kingdom which aren't part of The United Nations Convention on Contracts for the International Sale of Goods. Also in the contracting states the companies, lawyers, courts perceive, interpret and involve CISG in different ways based on their interests. Most of the contracting countries often exclude the CISG. The United Nations Convention on Contracts for the International Sale of Goods itself allows the contracting states to derogate. For this reason I'm going to give an overview of CISG and the problems with its applicability.
\end{abstract}

Keywords: CISG, Applicability, Lui Uniforme, Private International Law, reservations

\section{Introduction}

The United Nations Convention on Contracts for the International Sale of Goods (CISG) is an important example of attempts towards the unification of the international private law.

The CISG is seen as a big success with eighty three contraction states, most of them are important states that lead and rule the world's largest economies. The set goal of CISG to achieve a uniformed law is achieved-Loi uniforme (uniformed law) because the states which have signed, ratified and applied it. These countries by doing so have lead to the character of UNIFORME Law which has become clear. CISG aims to create uniform rules followed by uniform interpretation.

However, is it entirely true that CISG creates uniformity in contracts for international sales of goods? There are countries such as United Kingdom which aren't part of The United Nations Convention on Contracts for the International Sale of Goods. Also in the contracting states the companies, lawyers, courts perceive, interpret and involve CISG in different ways based on their interests. Most of the contracting countries often exclude the CISG.

The United Nations Convention on Contracts for the International Sale of Goods itself allows the contracting states to derogate. For this reason I'm going to give an overview of CISG and the problems with its applicability.

\section{The importance of CISG in inte rnational trade}

The United Nations Convention on Contracts for the International Sale of Goods (CISG1) is widely known as the key engine of the International Trade Law. In thirty five years, this convention has been accepted and ratified by eighty three countries ${ }^{2}$ from all over the world. These countries are "both

11980 UN Convention on Contracts for the International Sale of Goods. The CISG came into force on January 1, 1988

279 of 197 
industrial nations and developing states"3 from different corners of the world. "The self-executing treaty aims to reduce obstacles to international trade, particularly those associated with choice of law issues, by creating even-handed and modern substantive rules governing the rights and obligations of parties to international sales contracts." 4

Almost all countries of western world except United Kingdom are members of CISG, "even though it is interesting to note that even in UK courts, the CISG finds its way in as an expression of customary law." The CISG has been applied in a huge amount of financial transactions in each corner of the world; this fact gives CISG an important role in the unification of the International Trade Law, "the CISG has been recognized as the most successful attempt to unify a broad area of commercial law at the international level."

The CISG was a success at the height of the Cold War because most of the important and major trading countries such as United States and Russia have ratified the convention. The CISG offered to the contracting parties a different, neutral and innovative law to be applied in different jurisdictions for cross-border transactions ${ }^{7}$ In this way the convention tried to create a new set of rules which were intending to govern the international trade.

With eighty three contracting parties coming from every corner of the world, from different economic and political systems and different amount of importing and exporting has given to CISG a huge importance as it "represents three-quarters of all world trade".

Despite the importance of CISG "most authors identify three persistent problems of the CISG: its problematic uniform application by national and arbitral courts in the contracting states, its regular exclusion by parties, and its incompleteness" ${ }^{\prime 8}$. The Convention's ap plicability has been raised as issue in many state courts or arbitral tribunals, but there are still many issues regarding the applicability that have not yet any decision. ${ }^{9}$ Even when superficially it may be believed that a uniformity has been achieved which is an artificial uniformity " uniform application of the agreed rules is by no means guaranteed, as in practice different countries almost inevitably come to put different interpretations up on the same enacted words"10.

"This calls for recognition that the establishment of a global uniform law is not the only possible way in which international trade can be promoted. It would be equally important to allow parties to make the national jurisdiction of their choice applicable to the contract. The value of the CISG then lies primarily in providing commercial parties with a common frame of reference, allowing

them to compare the solutions of the CISG with various national jurisdictions and to act upon this." 11

Another problem is that most of the important countries such as Netherlands, United States and Germany exclude most of the time CISG applicability. It is important to point out as mentioned before that the United Kingdom hasn't ratified CISG and one of the reasons is the UK's familiarity with Sale

${ }^{3}$ Huber P\& Mullis A, 'The CISG-A new textbook for students and practitioners',(2007) European Law Publishers 26

4 Flechtner M.H (2009) United Nations Audiovisual Library of International Law 1 www.un.org/law/avl

${ }^{5}$ Dr.Andersen C.B. 'Recent removals of reservations under the international sales law winds of change heralding a greater unity of the CISG Journal of Business Law', (2012) 1

6 Flechtner M.H (2009) United Nations Audiovisual Library of International Law 1 www.un.org/law/avl

${ }^{7}$ Monaghan Ch, 'Voluntary harmonisation of sales law? The Common European Sales Law and the effect it will have on cross-border transactions',(2012) Company Lawyer 1

${ }^{8}$ Maastricht European Private Law Institute Working Paper No. 2013/1 Jan M.Smits pg.6

${ }^{9}$ Ferrari F, 'Overview of case law on the CISG's international sphere of application and its applicability requirements (articles 1(1)(A) and (B))' (2002) International Business Law Journal

${ }^{10}$ R.J.C. Munday, Comment, The Uniform Interpretation of International Conventions, 27

International and Comparative

Law quarterly, 1978, 450.

${ }^{11}$ Maastricht European Private Law Institute Working Paper No. 2013/1 Jan M.Smits pg.6 
of Goods Act. ${ }^{12}$ " There is a feeling in some quarters that the CISG was a utopian dream that has not lived up to its promise to provide a uniform law for international sales of goods." 13

\section{Sphe re of Application}

Part I of the CISG determines its sphere of application and introduces a few general provisions. Article 1 of the CISG states:

"(1) This Convention applies to contracts of sale of goods between parties whose places of business are in different States:(a) when the States are Contracting States; or(b) when the rules of private international law lead to the application of the law of a Contracting State.(2) The fact that the parties have their places of business in different States is to be disregarded whenever this fact does not appear either from the contract or from any dealings between, or from information disclosed by, the parties at any time before or at the conclusion of the contract.(3) Neither the nationality of the parties nor the civil or commercial character of the parties or of the contract is to be taken into consideration in determining the application of this Convention."

The parties may also exclude the CISG and choose the application of National Law. According to article 6 of CISG "The parties may exclude the application of this Convention or, subject to article 12 , derogate from or vary the effect of any of its provisions". So, it should be stated in the contract whether the parties are going to use or not the CISG clauses or if they are going to be modified. "Even if both parties are from contracting states they may still choose to be governed by Member States law to the exclusion of the CISG. Article 6 of the CISG allows the parties to exclude the application of the CISG in whole or in part."14

The article 6 constitutes Ius Dispositivum-the right to derogate, it "permits the parties to derogate from them or vary their effect, e.g., by merger clauses. This Opinion considers some issues that arise when a court or tribunal is asked to determine whether the parties intended by a merger clause to derogate from the Convention's norms governing contract interpretation." 15

\section{Applicability-significant countries}

\section{As mentioned before, article 1 of CISG determines the application of CISG}

"The CISG provides for two ways in which it will become the law of the contract.
First, through Article 1(1)(a), the CISG applies when both parties to the contract
of sale have their places of business in different States that are both Contracting
States. For example, if a company with its place of business in Germany sells to
one with its place of business in the People's Republic of China (PRC), the CISG
applies because both Germany and the PRC are Contracting States. Germany is
bound by Article 1(1)(a). If however a French company (France being a
Contracting State) enters into a contract of sale with an Indonesian company
(Indonesia is not a Contracting State as of today), the CISG cannot apply through

${ }^{12}$ Carr I, International Trade Law (Routledge, 2009), pp.57-60

${ }^{13}$ Huber P\& Mullis A, The CISG-A new textbook for students and practitioners, Sellier. European Law Publishers, 2007 (preface pg.8)

${ }^{14}$ Huber P\&Mullis A, The application in the contracting states of the United Nations Convention on Contracts for the International Sale of Goods (CISG) (Sellier.European Law Publishers, 2007) pg.2 http://www.hp-legal.com/

${ }^{15}$ CISG-AC Opinion no 3, Parol Evidence Rule, Plain Meaning Rule, Contractual Merger Clause and the

CISG, 23 October 2004. Rapporteur: Professor Richard Hyland, Rutgers Law School, Camden, NJ, USA. 
article 1(1)(a) since one of the parties has its place of business in a noncontracting state."16

The CISG applies even when one or both parties don't have their place of business in a contracting country of CISG. CISG applies "when the rules of private international law lead to the application of the law of a Contracting State"17.For example if British and French companies choose as the governing law of the contract French law, the CISG would normally apply because France is a contracting state despite the fact that United Kingdom is not a contracting state of CISG. Parties are free to choose CISG as the governing law, even thought that parties include CISG in only nine percent ${ }^{18}$ of their contracts. This statistically data gives us an overview on CISG applicability in most of the contracting parties.

\section{Problems with the applicability of the CISG and its Reservations}

There are different versions of the CISG which are applied in different countries. For that reason it is difficult to have the uniformity of application and as result also the uniformity of application of CISG as long as the reservations exist.

Article 93 of the CISG allows a contracting state if it is a Federal State to not apply the convention in all territories. Based on this article Australia has declared that this convention will not be applied to Ashmore, Cartier etc, New Zeland and Denmark as well have done the same declaration for some of their territories.

Based on the article 94 of The United Nations Convention on Contracts for the International Sale of Goods, two or more contracting states which have almost the same or the same governing legislation on matters governed by CISG should decide to declare that the Convention when the contracting states have their place of business on those countries. Countries such as Finland, Denmark, Norway and Sweden have made such declarations. ${ }^{19}$

"There are five permissible reservations of the CISG, which fall into three main categories." 20 Reservations which may prohibit, limit the application and alter the rules of the CISG. ${ }^{21}$

CISG art.94 states:

"(1) Two or more Contracting States which have the same or closely related legal rules on matters governed by this Convention may at any time declare that the Convention is not to apply to contracts of sale or to their formation where the parties have their places of business in those States. Such declarations may be made jointly or by reciprocal unilateral declarations.(2) A Contracting State which has the same or closely related legal rules on matters governed by this Convention as one or more non-Contracting States may at any time declare that the Convention is not to apply to contracts of sale or to their formation where the parties have their places of business in those States.(3) If a State which is the object of a declaration under the preceding paragraph subsequently becomes a Contracting State, the declaration made will, as from the date on which the Convention enters into force in respect of the new Contracting

${ }^{16}$ Huber P\&Mullis A, The application in the contracting states of the United Nations Convention on Contracts for the International Sale of Goods (CISG) (Sellier.European Law Publishers, 2007) pg.2 http://www.hp-legal.com

${ }^{17}$ Article 1(1)(b) CISG.

${ }^{18}$ Commission, "A Common European Sales Law to facilitate cross-border transactions in the Single Market" (2011), p.5 fn.21, http://eurlex.europa.eu/LexUriServ/LexUriServ.do? uri=COM:2011:0636:FIN:EN:PDF

${ }^{19}$ Ferrari $\mathrm{F}$ (ed.), Old Issues Revisited in the Light of Recent Experience (Milano: Giuffrè, 2003), pp.109-110; see http://www.cisg.law.pace.edu/cisg/text/e-text-94.html\#schol; http://www.cisg.law.pace.edu/cisg/countries/cntries.html

${ }^{20}$ Dr.Andersen C.B. 'Recent removals of reservations under the international sales law winds of change heralding a greater unity of the CISG Journal of Business Law', (2012) 2

${ }^{21}$ Dr.Andersen C.B. 'Recent removals of reservations under the international sales law winds of change heralding a greater unity of the CISG Journal of Business Law', (2012) 
State, have the effect of a declaration made under paragraph (1), provided that the new Contracting State joins in such declaration or makes a reciprocal unilateral declaration."

Contracting parties of CISG should also have in mind that the scope of application of the Convention is limited through the concept of goods. Also the fact that CISG has no requirement according to the form of the contract, the problem that is raised is when deciding for the contracting party at which stage it will become bound by a promise.

"Article 5 could give rise to some doubt as to whether the exclusion with respect to the seller's liability for death and personal injury claims should be interpreted a contrario so that his liability for property damage caused by defective products is encompassed by CISG. It is probably the better view that it is, but the problem then remains to decide whether, and to what extent, the buy er enjoys dual remedies in contract and tort." 22

Another problem is whether the United Nations Convention on Contracts for the International Sale of Goods governs the whole contract or only specific issues ${ }^{23}$. The CISG itself it is a statutory authority which interprets contract's provisions and governs different issues whether addressed or not by the contract.

One important problem in the unification of the private law is that there is no supreme court to give the interpretation of the United Nations Convention on Contracts for the International Sale of Goods, so in this way most of the lawyers prefer to use the domestic law to govern the international sales transactions rather that the CISG.

Article 7(1) sets out that: "In the interpretation of this Convention, regard is to be had so its international character and the need to promote uniformity in its application and the observance of good faith in the international trade." So it should be a uniform interpretation, but it doesn't exist a uniform interpretation as long as the decisions are being taken by national courts or arbitral courts and no supreme court exists.

Many signatory countries based on Article 94 of CISG have made different reservations for example a reservation was made by Singapore ${ }^{24}$. "The effect of the reservation is to limit the scope of application of the CISG so that, under Singapore law, the CISG will apply to contracts of sale of goods between parties from different states only when both the states are Contracting States, and the CISG will not apply where one of the parties is not from a Contracting State." ${ }^{25}$

\section{Article 95 of the CISG provides that:}

"Any State may declare at the time of the deposit of its instrument of ratification, acceptance, approval or accession that it will not be bound by sub-paragraph (1) (b) of article 1 of this Convention." Fortunately, this reservation has been removed by St Vincent, Grenadines, United States and by China. Also the People Republic of China in the time of the CISG ratification made a reservation under the article 96, by requiring that contracts should be only in writing, but recently PRC has removed this reservation. Therefore, to ensure the smooth operation of the CISG as the governinglaw of the contract, the phrase "without regard to any national reservation was added. ${ }^{26}$

The good news is that there are a considerable number of states which are taking out the reservations. It is optimistic the fact that many countries in regional level are taking out the reservations by creating in this way a uniformity in CISG application in regional level.

22 Patanjali A, 'A comparative study and analysis of the doctrine of frustration under the CISG, UNIDROIT Principles and UCC', (2012 ) International Company and Commercial Law Review 4

23 Any State may declare at the time of the deposit of its instrument of ratification, acceptance, approval or accession that it will not be bound by sub-paragraph (1) (b) of article 1 of this Convention www.cis gw3.law.pace.edu/cis g/biblio/butler6.html

${ }^{24} \mathrm{http}: / /$ cisgw3.law.pace.edu/cisg/countries/cntries-Singapore.html

${ }^{25}$ CISG - Review of Article 95 Reservation Executive Summary

${ }^{26}$ Moens G.A \&Sharma R, 'The CEAC Hamburg Arbitration Rules: a European-Chinese trade-related

adaptation of the revised UNCITRAL Arbitration Rules 2010'(2013) Arbitration 11 


\section{Conclusions}

Through this, I have described and analysed The United Nations Convention on Contracts for the International Sale of Goods, its application and reservations. CISG is for sure, a successful attempt of unification of International Private Law, but having in mind the period when it has been drafted and for the diplomatic reasons, in order to avoid the disputes it has been object of different reservations. Without the reservations, it should have been almost impossible for The United Nations Convention on Contracts for the International Sale of Goods without to be created and ratified. It is true and obvious that reservations where necessary in the period when the CISG was drafted, but there are no reasons for remaining still in today's practices. Also there are many matters which are not governed by the CISG such as services etc. So it still remains a set of international rules, which has to always compete with national jurisdictions. It is difficult to create uniformity, even when there is an artificial uniformity, it cannot be guaranteed that will be applied the same rules, as the experience has showed that different countries makes different interpretations for the same things as long as a supreme court doesn't exist for the CISG cases. We can't say that the CISG has reached the goal as long that there is no supreme court to give the interpretation of the CISG, when most of the lawy ers prefer to use the domestic law to govern the international sales transactions rather that the CISG. Also CISG is excluded by the parties in the majority of times. This proves that it has not achieved its goal of becoming uniform. But in any case, having in mind the attempts of many countries to remove the reservations which have become unnecessary, it is seen a good step towards the CISG success and it's uniformity which are not easy to be achieved,

\section{Bibliography}

1. Carr I, International Trade Law (Routledge, 2009)

2. Ferrari F (ed.), Old Issues Revisited in the Light of Recent Experience (Milano: Giuffrè,2003)

3. Huber P\& Mullis A, The CISG-A new textbook for students and practitioners, (Sellier. European Law Publishers, 2007)

4. Andersen C.B. 'Recent removals of reservations under the international sales law - winds of change heralding a greater unity of the CISG Journal of Business Law', (2012)

5. Ferrari F, 'Overview of case law on the CISG's international sphere of application and its applicability requirements (articles 1(1)(A) and (B))' (2002) International Business Law Journal

6. Huber P\& Mullis A, 'The CISG-A new textbook for students and practitioners',(2007) European Law Publishers

7. Huber P\& Mullis A, 'The CISG-A new textbook for students and practitioners',(2007) European Law Publishers

8. Moens G.A \&Sharma R, 'The CEAC Hamburg Arbitration Rules: a European-Chinese traderelated adaptation of the revised UNCITRAL Arbitration Rules 2010'(2013) Arbitration

9. Monaghan $\mathrm{Ch}$, 'Voluntary harmonisation of sales law? The Common European Sales Law and the effect it will have on cross-border transactions',(2012) Company Lawyer.

10. Maastricht European Private Law Institute Working Paper No. 2013/1 Jan M.Smits pg.6 